\title{
NUMERICAL SIMULATION OF AN EQUILIBRIUM SEGREGATION OF IMPURITIES ON THE GRAIN BOUNDARIES OF COPPER AND ITS ALLOYS
}

\author{
NUMERIČNA SIMULACIJA ENAKOMERNEGA LOČEVANJA \\ NEČISTOČ PRI ZRNATOSTI BAKRA IN NJEGOVIH ZLITIN
}

\author{
Wojciech Ozgowicz \\ Silesian University of Technology, Faculty of Mechanical Engineering, Konarskiego 18a, 44-100 Gliwice, Poland \\ wojciech.ozgowicz@polsl.pl \\ Prejem rokopisa - received: 2014-07-29; sprejem za objavo - accepted for publication: 2016-06-06
}

doi:10.17222/mit.2014.123

\begin{abstract}
The presented paper deals with a numerical simulation of vacancy diffusion of sulphur, tin and phosphorus atoms to the grain boundary of the structure of copper, type (2D). It was theoretically applied to analysed model alloys of types $\mathrm{Cu}-\mathrm{S}$ and $\mathrm{Cu}-\mathrm{Sn}$, particularly tin bronzes. Its purpose is to verify the obtained experimental results concerning this phenomenon, making use of the Auger method of spectroscopy of electrons (AES). Distinct effects of the segregation of sulphur atoms in the monolayer at the grain boundaries were found as well as an enrichment of the grain boundaries with tin atoms. In addition, the visualization of the simulation revealed a possible formation of stationary clusters of vacancies and segregating atoms on the analysed matrix of the atom structure (2D). The simulated effects of the segregation of S and Sn to the grain boundary, analysed as a function of the number of the cycles of the simulation are characterized by a statistically good repeatability of the results.

Keywords: copper alloys, grain-boundary segregation, diffusion, intercrystalline hot brittleness, mathematical model, numerical
\end{abstract} simulation

Pričujoče delo predstavlja numerično simulacijo odsotnosti zrn pri difuziji atomov žvepla, kositra in fosforja pri strukturi bakra, tipa 2D. Ta se uporablja za teoretično analiziranje modelov zlitin tipa $\mathrm{Cu}-\mathrm{S}$ in $\mathrm{Cu}-\mathrm{Sn}$, zlasti kositrnih in bronastih. Namen je, da bi pridobljene eksperimentalne rezultate preverili z uporabo AES (Augerjeva elektronska spektroskopija). Ugotovili smo različne učinke tvorjenja ločevanja atomov žvepla v monosloje na mejah zrn pa tudi obogatitev zrn $\mathrm{z}$ atomi kositra na mejah zrn. Hkrati pa je vizualizacija simulacije pokazala morebitno nastajanje nepremičnih grozdov praznin in ločevanja atomov $v$ analizirani matriki strukture atomov (2D). Simulirani učinek ločevanja S in Sn do meje zrn, analizirani v odvisnosti od števila ciklov simulacije kaže na značilno statistično dobro ponovljivost rezultatov.

Ključne besede: bakrene zlitine, ločevanje zrnc, difuzija, interkristalna krhkost na vročem, matematični model, numerična simulacija

\section{INTRODUCTION}

The segregation of admixed or impurity atoms at the boundaries of the grains and on free surfaces proceeds in accordance with two basic mechanisms, viz., equilibrium segregation (ES) ${ }^{1-3}$ and non-equilibrium segregation (NES). ${ }^{4-8}$ Generally, equilibrium segregation is applied in the course of a diffusive displacement of substituted or interstitial atoms to structurally disturbed interphase surfaces, such as the grain boundaries and free surfaces or to regions of dislocation and stacking faults, causing free energy reduction of the elastic lattice misfit. A reduction of this energy constitutes the driving force of the process ES. Concentrating their attention on metals and binary alloys, M. P. Hondros, E. D. Seah ${ }^{1}$ proved that there is a direct relation between the degree of segregation and the temperature of the process, which may be expressed with Equation (1):

$$
\frac{C_{b}}{C_{g}}=A \exp \left(\frac{E}{k T}\right)
$$

where $C_{\mathrm{b}}$ denotes the concentration of the segregating atoms at the grain boundaries, $C_{\mathrm{g}}-$ the concentration of these same atoms in the undisturbed fragments of the structure, $A$ and $k$ - constant values ( $k$ - Boltzmann constant) and $E$ - the free energy of segregation, i.e, the reduction of the energy of the segregating atoms in the place of segregation, e.g., at the grain boundary. Usually atoms with a considerable free energy of segregation indicate a much greater differentiation of atomic radiation and electronic structure then the atoms of the matrix. ${ }^{9}$

The quantity of segregation at the grain boundaries, expressed with Equation (1) disregards, however, the dependence of segregation on time and, in the first stage of modelling, this is a considerable shortcoming because the diffusion of the segregating atoms is an essentials element of the ES mechanism. D. McLean ${ }^{10}$ defined this dependence even more accurately by taking into account the required accumulation of a monolayer of the segregating atoms, controlled by the diffusion of the atoms in the matrix $D_{\mathrm{i}}$. This effect is defined with 
Equation (2), in which diffusion temperature $T$ appears implicitly as $\alpha=\alpha(T)$ :

$$
\frac{C_{x}-C_{g}}{C_{b}-C_{g}}=1-\exp \left(\frac{4 D_{i} t}{\alpha^{2} d_{i}^{2}}\right) \operatorname{erfc} \sqrt{\left(\frac{4 D_{i} t}{\alpha^{2} d_{i}^{2}}\right)}
$$

where: $C_{\mathrm{s}}-$ concentration of the segregating atoms at the grain boundaries in the time $t ; \alpha=C_{\mathrm{b}} / C_{\mathrm{g}} ; d_{\mathrm{i}}-$ potential width of the grain boundary.

Equation (2) permits us to assess the kinetics of the ES phenomenon at the grain boundary and to predict rather precisely - the duration and temperature of the process, for example the temper brittleness of steel due to the equilibrated segregation of phosphorus. ${ }^{2}$

In recent years much attention has been paid to the mechanism NES, particularly with respect to steel and heat treatment. The theoretical fundamentals concerning this phenomenon were dealt with by K. T. Aust et al. ${ }^{4}$ and R. Anthony ${ }^{5}$, and later by R. G. Faulkner ${ }^{3,8}$ focusing mainly on the developed. The mechanism NES based on the formation of complexes of point defects in the structures of the alloys, mainly of the vacancy-atom type of admixture or impurity, as well as gradients of the concentrations of vacancies in the vicinity of the areas of an intensive elimination of point deffects. Such adsorbents of vacancies are interphase surfaces or grain boundaries and also free surfaces. Non-equilibrium segregations take place in the course of accelerated cooling of the alloy in the conditions of large temperature differences if, for instance, the vacancy-atom pairs of impurity diffuse in the gradients of concentration in the direction of their decreasing concentration. In such conditions the equilibrium concentration of the vacancies and complexes is reduced, and the actual concentration can take place only in the regions of the sink of vacancies.

This process is illustrated quantitatively with the diagram on Figure 1. The quantity of NES is characterized by the quotient of concentrations $C_{\mathrm{b}} / C_{\mathrm{g}}$, and the extent of this effect is expressed by the distance $\mathrm{x}$ from the grain boundaries, at which the concentration of im-

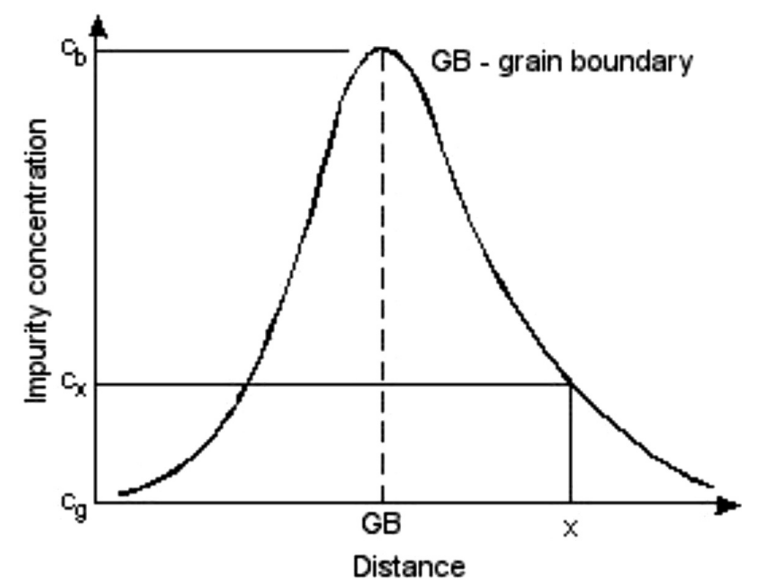

Figure 1: Magnitude and extent of non-equilibrium segregation Slika 1: Magnituda in obseg neenakomernega ločevanja purities attains the lowest level. For the purpose of describing this process quantitatively, it is of essential importance to determine the changes of the curve of the distribution of concentration depending on the time, the temperature and the size of the grains. These parameters can be easily related to the conditions of the heat treatment of the investigated alloys.

An alternative for the description of complex effects in the mechanisms of equilibrium segregation and non-equilibrium segregation by means of phenomenological equations of diffusion is computer aided modelling of these segregations at the grain boundaries of polycrystals, on the atomic scale, applying the method of simulating elementary overshoots of the determined atoms in stable nodal orientations of the structure type (2D). ${ }^{11-14}$ In such a case, we move away from the macroscopic phenomena, described by Fick's laws, to the microscopic mechanism of diffusion. However, frequently repeated simulations of individual jumps of diffusion permit us to assess the resulting segregations on the macroscopic scale. In the mathematic model ${ }^{11}$ assumed and applied for the computer simulation, the mutual energy concentration between the point defects and grain boundaries were utilized at the atomic level in order to predict the motion of the atoms of impurities, thus resulting in the segregation. The model simulates, in a somewhat simplified way, the vacancy mechanism of the lattice diffusion in metals, particularly the migration of the admixture atoms of impurities and also the vacancies to the grain boundaries, based on an analysis of the effects of the energy in the environment on the respective elements of the lattice, distributed stochastically in the matrix..$^{15-16}$ An advantage of this way of modelling is the possibility of simulating complex effects of the processes ES and NES without having to apply equations of the rate of diffusion.

The aim of the investigations was, therefore, to simulate numerically the phenomenon of intercrystalline segregation of the components of alloys and impurities in some selected alloys of copper, particularly tin bronzes, in order to verify the obtained experimental results concerning this phenomenon, making use of the Auger method of spectroscopy of electrons (AES).

\section{EXPERIMENTAL PART}

\subsection{Materials and methods}

Experimental investigations were carried out on tin bronzes of the type CuSn6P, resulting from industrial smelting in the firm Trefimetaux (in France), in the form of bars with a diameter of $10 \mathrm{~mm}$, smelted continuously (process Wertli) and with the chemical composition quoted in Table 1. Comparative investigations concerning intercrystalline segregation, based on models of high-purity bronzes and bronzes modified with microadditions of rare-earth elements were dealt with earlier. ${ }^{17,18}$ 
Table 1: Chemical composition of the investigated alloy

Tabela 1: Kemijska sestava preiskovane zlitine

\begin{tabular}{|c|c|c|c|c|c|c|c|c|c|c|c|c|c|c|}
\hline \multirow{3}{*}{ Lp. } & \multirow{3}{*}{ Material } & \multicolumn{13}{|c|}{ Chemical composition, in mass fractions $(w / \%)$} \\
\hline & & \multirow{2}{*}{$\mathrm{Sn}$} & \multirow{2}{*}{$P$} & \multirow{2}{*}{$\mathrm{Cu}$} & \multicolumn{10}{|c|}{ Impurities } \\
\hline & & & & & $\mathrm{Bi}$ & $\mathrm{Pb}$ & $\mathrm{Sb}$ & As & $S$ & $\mathrm{Fe}$ & $\mathrm{Zn}$ & $\mathrm{Ni}$ & & $\mathrm{D}_{2}$ \\
\hline 1 & Industrial bronze & CuSn6P & 6.70 & 0.42 & 92.1 & 0.0100 & 0.0800 & 0.0100 & 0.0250 & 0.0026 & 0.0180 & 0.046 & 0.030 & - \\
\hline 2 & Model bronze & $\mathrm{CuSn6PM}$ & 6.70 & 0.33 & bal. & 0.0010 & 0.0040 & 0.0002 & 0.0003 & 0.0020 & 0.0060 & 0.010 & 0.002 & 0.0012 \\
\hline
\end{tabular}

Spectrometric investigations were carried out applying the Auger electron spectroscopy technique including the double ionized process of Auger electron emission, using, for this purpose, a spectroscope of the type Riber ASC 2000 (France). Essentially, the Auger emission process requires the excitation of a surface sample with a primary electron beam of $1-10 \mathrm{keV}$ and the detection of the characteristic Auger electrons with peaks well defined in the derivative of the secondary electron energy spectrum. These peaks are specific for the elements, from which the Auger electrons escape. The first process is X-ray fluorescence and the second one is Auger emission. Obviously, none of them can take place at the same initial core hole: thus, they compete. Furthermore, because Auger electrons arrive from depths of about several atom distances, from the point of view of vertical resolution, the technique appears to be an interesting surface analytical tool.

The applied spectrometer was equipped with a cylindrical electrostatic analyser of the energy of the emitted electrons of the type Mac-2 and a scanning electron microscope (SEM) with a spectrometer EDS as well as an electron gun with a high vacuum system, recording the results and controlling the complexity of the entire experiment. An Auger analysis of the energy of electrons was carried out on the surfaces of an intercrystalline fracture of the samples selected at random immediately after having been fractured in the chamber of the spectrometer. Samples with a strain rate of about $10^{-4} \mathrm{~s}^{-1}$ were statically stretched in the temperature range of minimum plasticity (DMT - ductility minimum tempe-

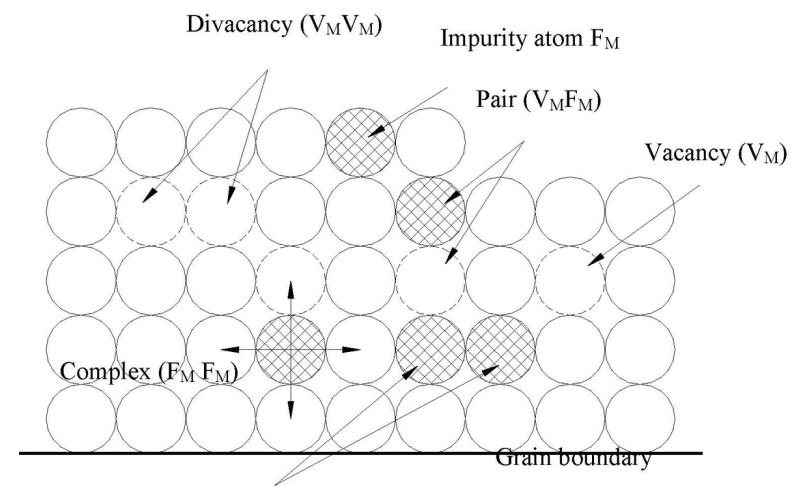

Figure 2: Diagram showing the interaction of lattice defects and possible directions of diffusion jumps simulated with the computer model in a (2D) structure

Slika 2: Diagram inmterakcije napak v mreži in možne smeri difuzijskih skokov, simuliranih z računalniškim modelom v 2D-strukturi rature), applying a tensile testing instrument specially designed for the study of fracture surfaces, equipped with a device for resistance heating of the strained samples. Some selected samples were also ionically etched in order to determine the gradient of the chemical composition of the monolayer in the function of the depth of etching from the boundary of the grain.

In order to simulate the process of diffusion of point defects to the grain boundary in the lattice (2D), the mathematical model suggested by Chapman and Faulkner ${ }^{11}$ was applied. In this model, the effect of energy was utilized at the level of an atom between the vacancies, the atoms of admixtures or impurities solved in the matrix and the grain boundaries in order to predict the motion of the atoms and the resulting way of segregation. In this model, the atom was assumed to be spherical and the surrounding crystalline lattice elastic, maintaining a constant volume. The interactions of the point effects provide energy driving forces, required to keep up the migration of the segregating atoms to the grain boundaries, and also to create complexes of defects, e.g., divacancies $\left(V_{\mathrm{M}} V_{\mathrm{M}}\right)$ or complexes of the vacancy type $\left(V_{\mathrm{M}}\right)$ - the admixture atom $\left(F_{\mathrm{M}}\right)$, the so-called pair $V_{\mathrm{M}} F_{\mathrm{M}}$, Figure 2 .

The applied model assumes a two-dimensional (2D) simulation of the migration of admixture atoms and impurities in the plane (100) of a six-walled lattice with dimensions $(n \times n)$ of the atoms, the grain boundary



Figure 3: Two-dimensional lattice plane (2D) and grain boundary simulated with the computer model

Slika 3: Dvodimenzionalna mreža 2D in zrna, simulirana z računalniškim modelom 
being situated in the centre of the plan, Figure 3. The grain boundary concentrates the atoms of impurities and the vacancies, which are annihilated after they have reached them. The point defects are initially distributed in the plane at random with given concentrations of the atoms. The mechanisms of segregation, desegregation and the formation of complexes are simulated based on a dynamic assessment of individual probabilities of a diffusive jump. These probabilities are multiplied by the factor of acceleration $W_{\mathrm{p}}$ in order to shorten the time of numerical calculations. Every cycle of the programme is modelled using $W_{\mathrm{p}} 10^{-13} \mathrm{~s}$ for the duration of the actual diffusion. Details concerning the model applied to simulate the process of diffusion had been presented in an earlier paper. ${ }^{19}$

\section{ANALYSIS OF THE RESULTS}

\subsection{Results of microfractographic investigations and Auger spectrometric analysis}

Industrial tin bronzes of the type CuSn6P, plastically deformed in the range of DMT, display an intercrystalline brittle fracture on microfractographs, Figure 4. Intercrystalline cracking, detected on the surfaces of crystalline grains at the boundaries, often run across the pores and defects characteristic for smelted structures. On intercrystalline surfaces, there are often distinct traces of plastic deformation and cavitation, Figures $\mathbf{4 c}$ and $\mathbf{4 d}$.

A spectrometric analysis in situ of the fractures of the investigated samples, fractured in the conditions of a high vacuum (UHV) permitted us to reveal the segregation of the admixture atoms and impurities at the grain boundaries, affecting essentially the process of intercrystalline cracking of the investigated tin bronzes. The results of the tests of tin bronze using the AES method and scanning electron microfractography are presented in Figures 5 and $\mathbf{6}$.

Auger emission spectrum recorded on the intercrystalline surfaces of bronze CuSn6P after its fracture in the range of DMT (about $300-600{ }^{\circ} \mathrm{C}$ ) indicates, besides reference lines $(\mathrm{Cu})$, also distinct lines of tin and sulphur as well as a double line of phosphorus, Figure 5a. The atypical shape of the $\mathrm{P}$ spectrum of the energy of electrons of the order of $117-120 \mathrm{eV}$ probably results from the specific atomic bond $\mathrm{Cu}-\mathrm{P}$. The occurrence of a doublet of this type was proved experimentally in the spectrum of the $\mathrm{Cu}_{3} \mathrm{P}$ phase. ${ }^{17}$ It was found that both the number of the analysed spectral lines and their intensity depend essentially on the temperature of deformation. ${ }^{20}$ It was also found that the tested walls of the fracture are distinctly enriched with $\mathrm{Sn}, \mathrm{S}$ and $\mathrm{P}$. Ionic etching $\left(\mathrm{Ar}^{+}\right)$ of the intercrystalline fractures of the CuSn6P bronze after the stretching in the range of DMT revealed that the $S$ concentration obviously decreases in the course of etching to about $90 \mathrm{~min}$, whereas the concentration of $\mathrm{Sn}$ decreases only inconsiderably and the concentration of $\mathrm{P}$
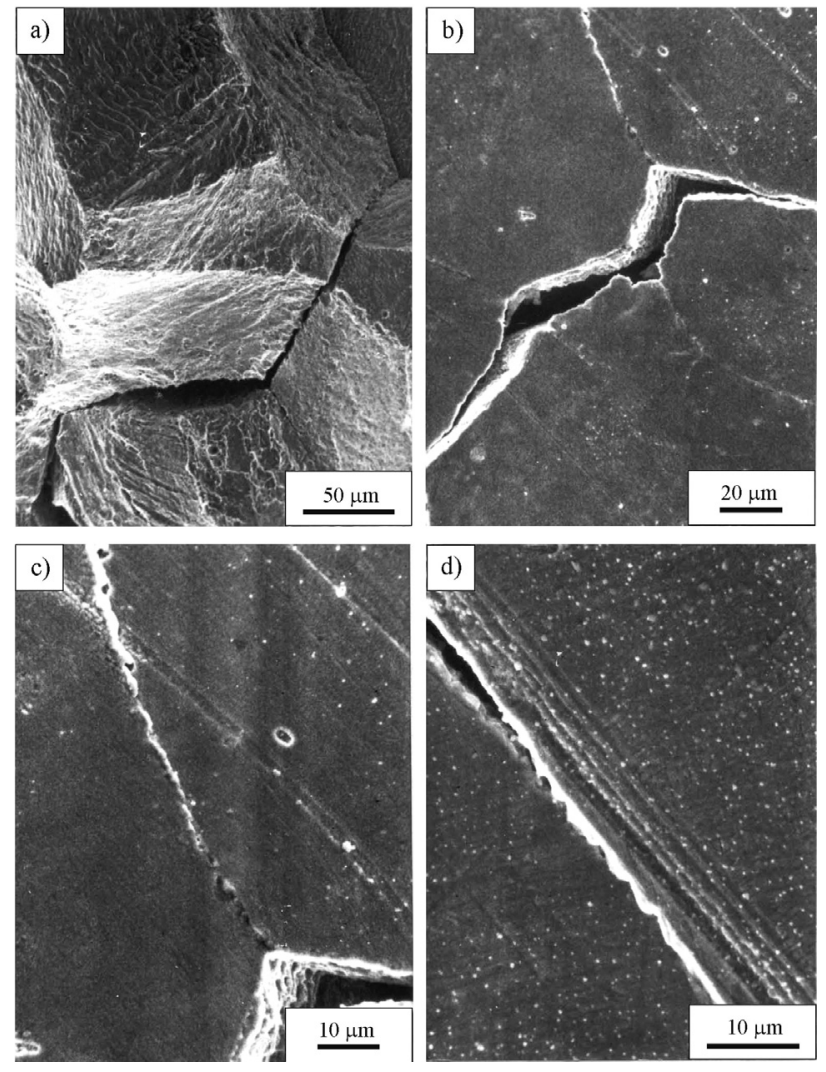

Figure 4: Fractography a) and intercrystalline fissures (b-d) of industrial bronze CuSn6P in the LR state after tensile tests at a strain rate of $10^{-5} \mathrm{~s}^{-1}$ and temperature of $400{ }^{\circ} \mathrm{C}$ : a) intergranular fracture, b) intercrystalline fissure, c) magnification of b), d) intercrystalline cavitations at the top of the fracture

Slika 4: a) Analiza površine zloma in (b-d) industrijskega brona CuSn6P in LR po nateznih preizkusih pri stopnji obremenitve $10^{-5} \mathrm{~s}^{-1}$ in tempreturi $400{ }^{\circ} \mathrm{C}$ : a) interkristalni zlom, b) interkristalna razpoka, c) povečava, d) interkristalne razpoke na vrhu zloma
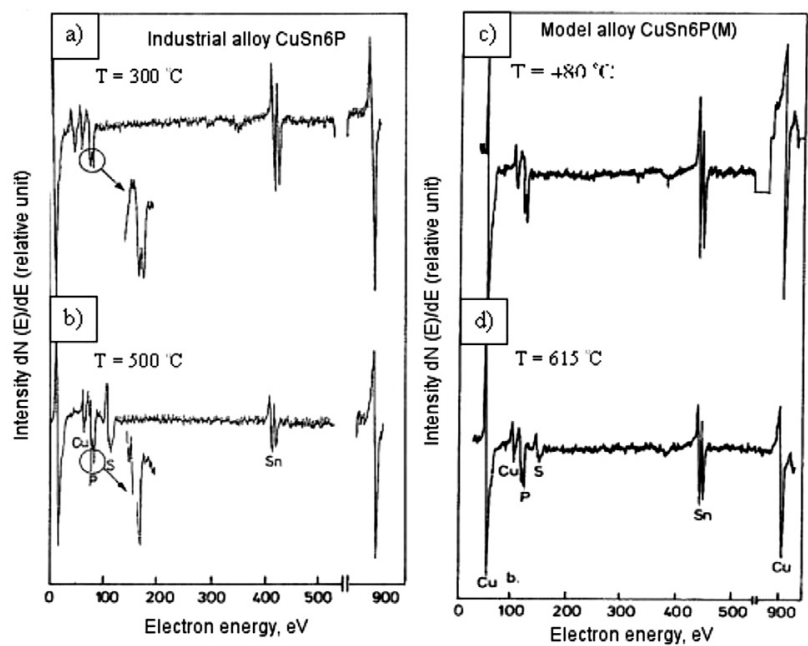

Figure 5: a) Auger spectrum of the intercrystalline fracture surface of industrial bronze CuSn6P and c) model bronze $\mathrm{CuSn6P(M)}$ after tensile tests at a) $300^{\circ} \mathrm{C}$ and c) $480^{\circ} \mathrm{C}$

Slika 5: a) Augerjev spekter interkristalne površine zloma pri industrijskem bronu CuSn6P in b) modelu brona $\mathrm{CuSn6P}(\mathrm{M})$ po nateznih preizkusih pri a) $300{ }^{\circ} \mathrm{C}$ in c) $480{ }^{\circ} \mathrm{C}$ 

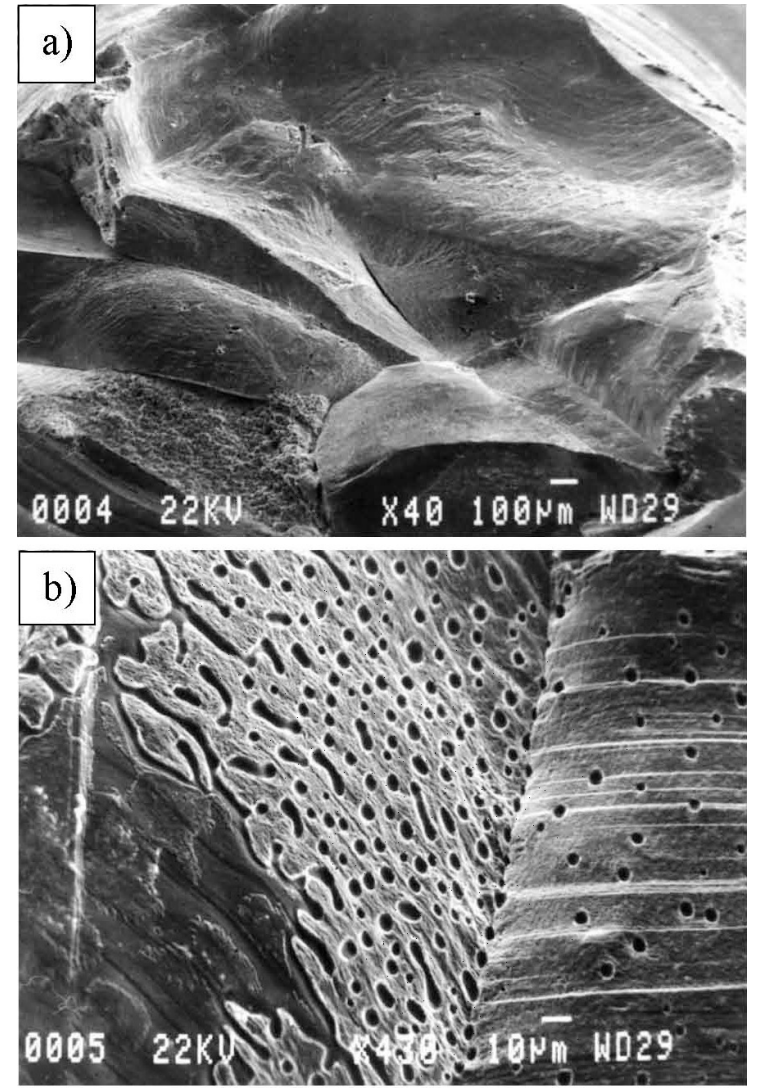

Figure 6: Fractography of industrial bronze CuSn6P analysed with the AES method after tensile tests at the temperature of $300{ }^{\circ} \mathrm{C}$ : a) intergranular brittle fracture, b) intergranular fracture with traces of plastic deformations of the surface

Slika 6: Analiza površine zloma pri industrijskem bronu CuSn6P, analiziranem z AES metodo po nateznih preizkusih pri temperaturi $300{ }^{\circ} \mathrm{C}$ : a) interkristalni krhki lom, b) interkristalni lom s sledovi plastičnih deformacij površine

practically does not decrease at all, Figure 7. The observed changes in the concentration of the components of the alloys $(\mathrm{Sn}, \mathrm{P})$ and $\mathrm{S}$ in the function of the time of etching prove the occurrence of the segregation of the atoms of these elements at the grain boundaries, probably clustered in monolayers or in the nanometric external layer.

\subsection{Results of numerical simulations of the intercry- stalline segregation}

Numerical simulations of diffusive segregations of admixture atoms and impurities at the grain boundaries of the investigated tin bronze was previously tested with the investigations of the probability of a migration of point defects in (2D) structures. The repeatability of the observed changes in the concentration of the diffusing atoms in the function of the time of simulation was analysed, taking into account the a priori assumed randomness of the process of the model of atomic diffusion. ${ }^{21}$ Besides, the operation of this programme was also tested in the case of the model alloys including a Fe- $0.75 \%$ amount fraction of $\mathrm{B}$ and $\mathrm{a} \mathrm{Cu}-0.75 \%$ amount fraction of $\mathrm{Bi}^{19}$

The simulations of the process of the migration of the atoms of sulphur and vacancies to the grain boundary of the model alloy including a $\mathrm{Cu}-0.75 \%$ amount fraction of $\mathrm{S}$ were performed for the analytically calculated values of the energy of bonding and migration, Table 2, and the assumed parameters of the simulation, the temperature of diffusion of $1000 \mathrm{~K}$, the dimensions of the analysed atomic plane of the grains of $100 \times 100$ atoms, the coefficient of acceleration $W_{\mathrm{p}}=10^{6}$ as well as

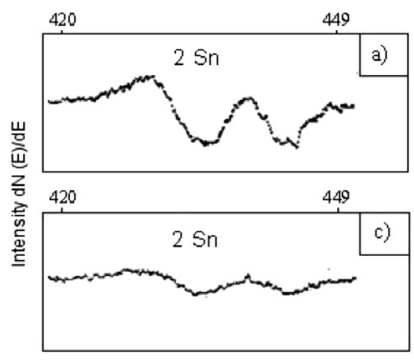

Electron energy, eV



Figure 7: Selective Auger spectrum of tin atoms from the intergranular fracture of bronze CuSn6P after tensile tests at $300{ }^{\circ} \mathrm{C}$ : a) before etching, c) after ion-bombardment etching with $\mathrm{Ar}^{+}, \mathrm{b}$ ) concentration profile of $\mathrm{Sn}$ and $\mathrm{P}$ and d) as a function of the time of ion etching

Slika 7: Selektivni Augerjev spekter atomov kositra iz imnterkristalnega zloma brona CuSn6P po nateznih preizkusih pri $300{ }^{\circ} \mathrm{C}$ a) pred jedkanjem, c) po ionskem jedkanju $\mathrm{z} \mathrm{Ar}^{+}$, b) profil koncentracije $\mathrm{Sn}$ in $\mathrm{P}$ in d) kot funkcija časa jedkanja

Table 2: Energy of migration and bonding of the lattice defects calculated for the model alloy Cu- $0.75 \%$ amount fraction of $\mathrm{S}$ Tabela 2: Energija migracij in povezave mrežnih napak, izračunane za model zlitine $\mathrm{Cu}-0.75 \%$ atomskih deležev $\mathrm{S}$

\begin{tabular}{|c|c|c|c|c|c|}
\hline \multirow[b]{2}{*}{ Kind of energy } & \multicolumn{5}{|c|}{ Kind of lattice defect } \\
\hline & Vacancy (v) & Divacancy (vv) & $\begin{array}{l}\text { Impurity atom } \\
\text { (i) }\end{array}$ & $\begin{array}{l}\text { Complex biatomic } \\
\text { impurity (ii) }\end{array}$ & $\begin{array}{l}\text { Complex vacancy } \\
\text { impurity (vi) }\end{array}$ \\
\hline Forming energy $E_{\mathrm{f}}(\mathrm{eV})$ & 1.49 & 2.87 & 1.54 & 3.03 & \begin{tabular}{|l|}
2.59 \\
\end{tabular} \\
\hline Migration energy $E_{\mathrm{m}}(\mathrm{eV})$ & 1.49 & - & 1.54 & - & - \\
\hline \multirow{2}{*}{ Kind of defect } & \multicolumn{5}{|c|}{ Energy of bonding $E_{b}(\mathrm{eV})$} \\
\hline & Vacancy & Impurity atom & \multicolumn{3}{|c|}{ Grain boundary } \\
\hline Vacancy & 0.14 & $0.34 * 0.44$ & \multicolumn{3}{|c|}{1.49} \\
\hline Impurity atom & $0.34 *$ & 0.04 & \multicolumn{2}{|c|}{$0.2 *$} & \\
\hline Grain boundary & 1.49 & $0.2 *$ & \multicolumn{3}{|c|}{0.10} \\
\hline
\end{tabular}

* alternative values adopted to program the simulation 


\section{W. OZGOWICZ: NUMERICAL SIMULATION OF AN EQUILIBRIUM SEGREGATION OF IMPURITIES ...}

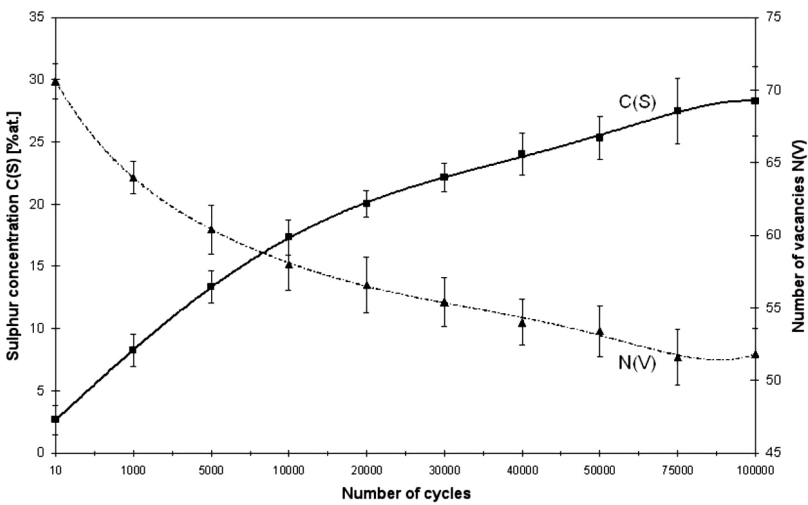

Figure 8: Dependence of the sulphur concentration and number of vacancies on the number of diffusion-simulation cycles concerning the model alloy $\mathrm{Cu}-0.75 \%$ amount fraction of $\mathrm{S}$ and $T=1000 \mathrm{~K}$

Slika 8: Odvisnost koncentracije žvepla in števila zasedenosti pri difuzija-simulacija ciklih za model zlitine $\mathrm{Cu}-0.75 \%$ atomskih deležev $\mathrm{S}$ in $T=1000 \mathrm{~K}$
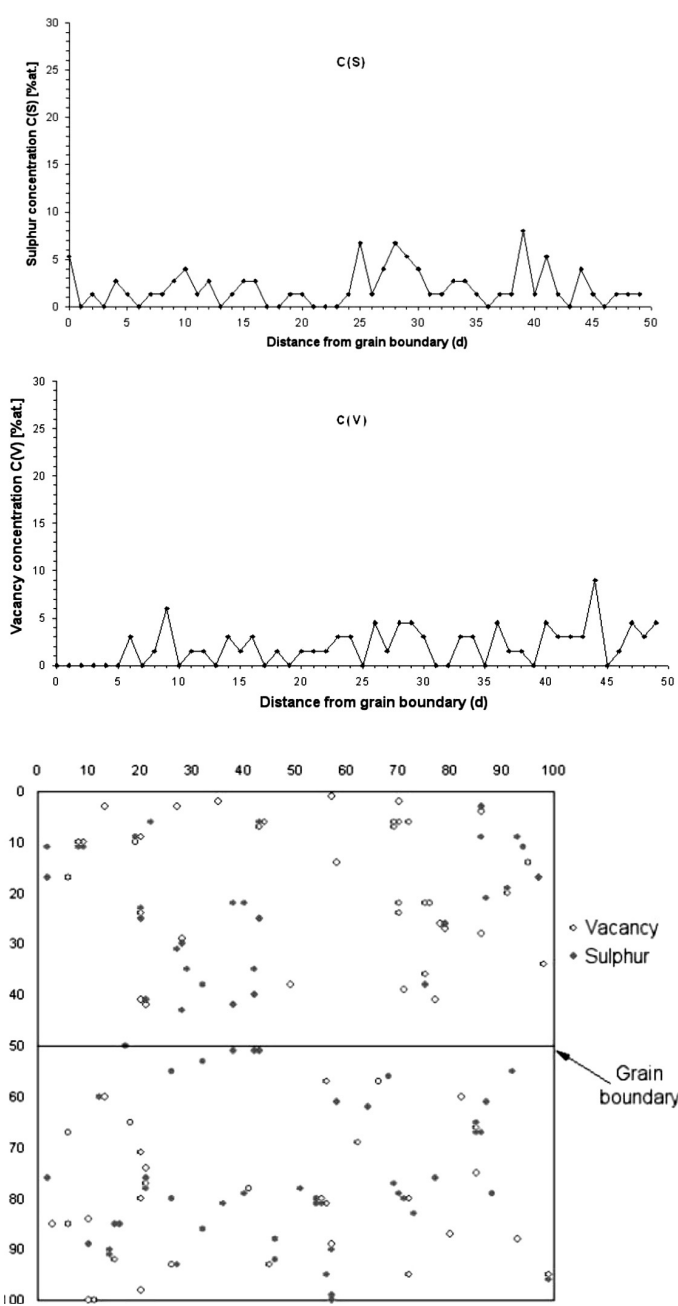

Figure 9: Distribution of sulphur and vacancy concentrations as a function of the distance from the grain boundary concerning the model alloy $\mathrm{Cu}-0.75 \%$ amount fraction of $\mathrm{S}$ and $T=1000 \mathrm{~K}$ after a simulation of $10^{3}$ cycles

Slika 9: Porazdelitev žvepla in koncentracija zasedenosti kot funkcija razdalje od mej zrn, model $\mathrm{Cu}-0.75 \%$ atomskih deležev $\mathrm{S}$ in $T=1000$ $\mathrm{K}$ po simulaciji $10^{3}$ ciklov the volumetric concentration of sulphur and the vacancy in the matrix of the alloy at the level of a $0.75 \%$ amount fraction in the range of up to 100 thousands of iterative cycles.

The results of the simulations are gathered in diagrams on Figures 8-13. The analysed mean values of the concentration of sulphur and the number of vacancies in the matrix as a function of the number of cycles of simulations concerning the results of five simulations indicate an intensive increase in the concentration of sulphur in the zone of the grain boundary to about $20 \%$ and in the case of about $2 \cdot 10^{4}$ cycles with a simultaneously distinctly decreased number of free vacancies in the matrix of the alloy, Figure 8 .

After the subsequent cycles of iterations (about $10^{5}$ ) the concentration of sulphur grows to about 25-30\% amount fractions and stabilizes at this level, forming clusters of vacancies and the atoms of sulphur in the
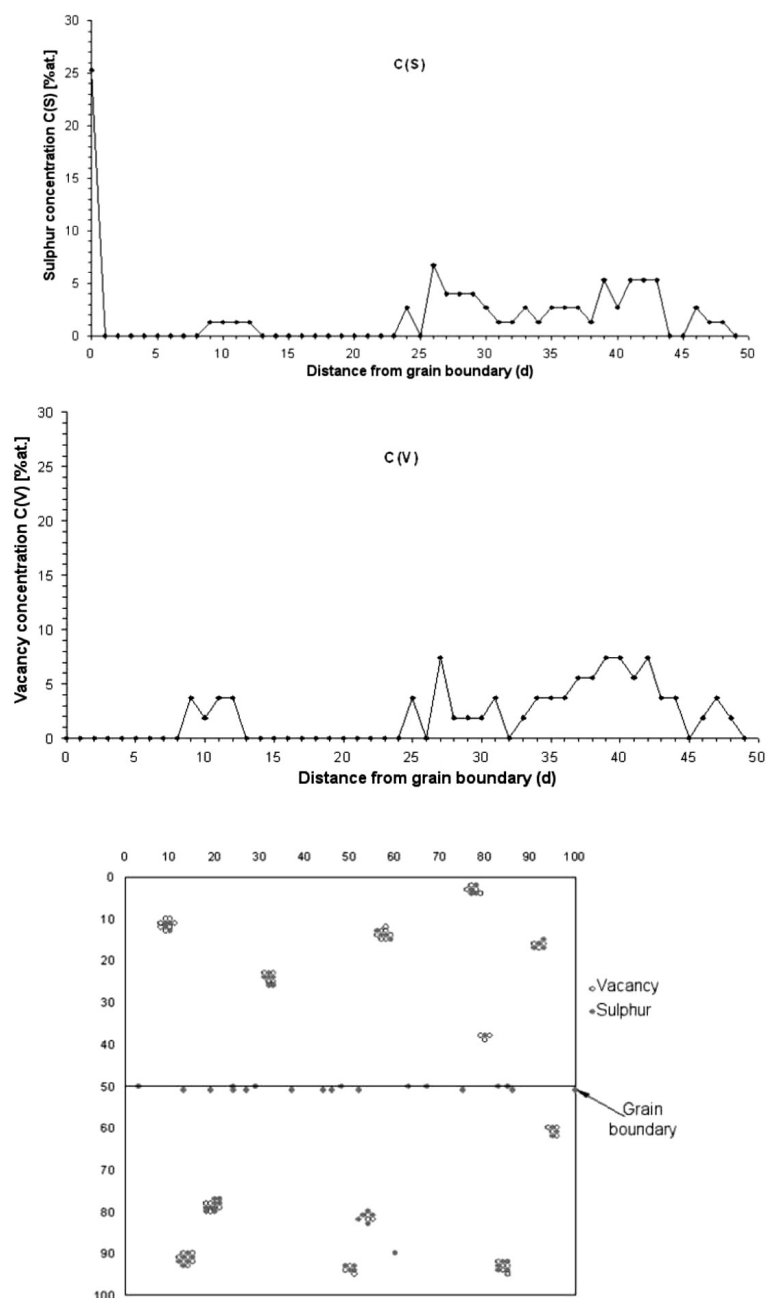

Figure 10: Distribution of sulphur and vacancy concentrations as a function of the distance from the grain boundary concerning the model alloy $\mathrm{Cu}-0.75 \%$ amount fraction of $\mathrm{S}$ and $T=1000 \mathrm{~K}$ after a simulation of $10^{5}$ cycles

Slika 10: Porazdelitev žvepla in področja koncentracij pri funkciji razdalje od mej zrn, model $\mathrm{Cu}-0.75 \%$ atomskih deležev $\mathrm{S}$ in $T=1000$ $\mathrm{K}$ po simulaciji $10^{5}$ ciklov 
areas distant from the grain boundary. Such a formation of the $\mathrm{C}(\mathrm{S})$ and $\mathrm{C}(\mathrm{V})$ concentrations proves the essential role of vacancies in the migration of sulphur atoms towards the grain boundary. The number of vacancies characterizes the amount of their flux in the direction of the grain boundary and the potential connection with the migration of the atoms of sulphur in this direction. The analysis of the kinetics of this process of migration of sulphur to the grain boundary proves that already after about $10^{3}$ cycles of the simulation the concentration of sulphur in the monolayer at the grain boundary attains a value of $5 \%$ amount fraction, Figure 9, and after $10^{5}$ cycles - about $25 \%$ amount fraction, Figure 10, accompanying the entire annihilation of the vacancies in this zone.

An increased concentration of vacancies to about $5-10 \%$ is also observed in the areas of the matrix distant from the grain boundary by about $30-40 \mathrm{~d}$, which indicates a nucleation of clusters of vacancies with the atoms of sulphur. These clusters may affect the atoms of impurities and free vacancies distributed stochastically in the matrix as additional sinks of defects. Thus, the size and distribution of stable clusters of point defects in the lattice may influence the extent of the resulting segregation of the atoms of sulphur on the grain boundary.

The assumed model simulating the diffusion of vacancies of point defects in the (2D) structure was also applied in the analysis of the influence of some parameters of simulation on the attained concentration of the atoms of sulphur at the grain boundary of the model alloy $\mathrm{Cu}-0.75 \%$ amount fraction of S, Figures 11-13. Among others, it was found that the simulated concentration of sulphur at the grain boundary increases slightly with a decrease in the initial concentration of vacancies in the matrix of the alloy, Figure 11. The maximum index of the enrichment of the grain boundary with the atoms of sulphur amounts to about 60 concerning the initial concentration of vacancies of the order of $0.1 \%$ amount fraction and the real time of migration of the

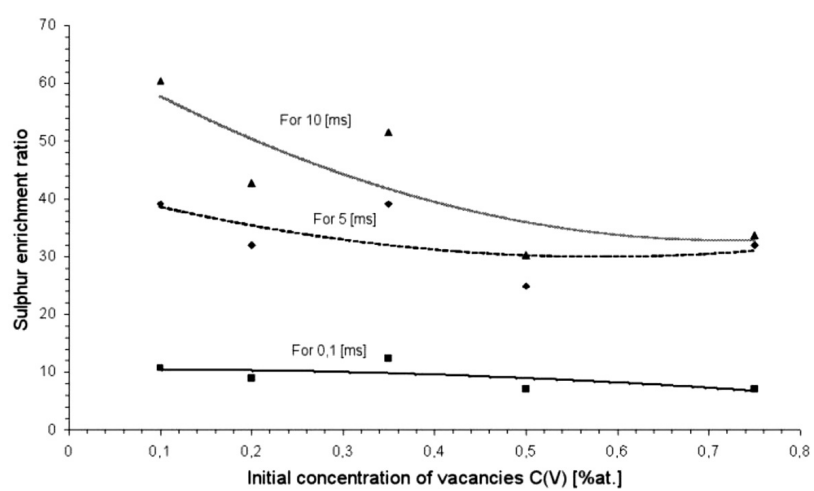

Figure 11: Dependence of the sulphur enrichment ratio at the grain boundary on the initial vacancy concentration in the case of model alloy $\mathrm{Cu}-0.75 \%$ amount fraction of $\mathrm{S}$ and $T=1000 \mathrm{~K}$

Slika 11: Odvisnost razmerja žveplove bogatitve na mejah zrn na začetni koncentraciji v primeru modela zlitine $\mathrm{Cu}-0,75 \%$ atomskih deležev $\mathrm{S}$ in temperaturi $1000 \mathrm{~K}$



Figure 12: Effect of the size of the atomic plane on the relation between the sulphur concentration and number of vacancies on the number of diffusion-simulation cycles concerning the model alloy $\mathrm{Cu}-0.75 \%$ amount fraction of $\mathrm{S}$ and $T=1000 \mathrm{~K}$

Slika 12: učinek velikosti ravnine atomov na relaciji med koncentracijo žvepla in številom vrzeli na število difuzijsko simulacijskih ciklov pri modelu zlitine $\mathrm{Cu}-0,75 \%$ atomskega deleža $\mathrm{S}$ in temperaturi $1000 \mathrm{~K}$

atoms is about $10 \mathrm{~ms}$. An increase of the analysed matrix to dimensions of $200 \times 200$ atoms, Figure 12, involves a proportional decrease of the atomic concentration of the atoms of sulphur in the function of the number of cycles, but without any essential qualitative changes in the analysed relation. The number of vacancies changes in a similar way. An evident effect on the simulation is exerted by the temperature of the process of diffusion, Figure 13. A drop in the temperature of diffusion by about $100 \mathrm{~K}$ results in a nearly twofold decrease in the concentration of the atoms of sulphur at the grain boundary and an inconsiderable change in the number of free vacancies in the matrix of the alloy in the investigated range of iterations.

Simulation of the vacancy diffusion of the atoms of tin to the grain boundary in the analysed model bronze $\mathrm{Cu}-3 \%$ amount fraction of $\mathrm{Sn}$, Table 3, showed that for

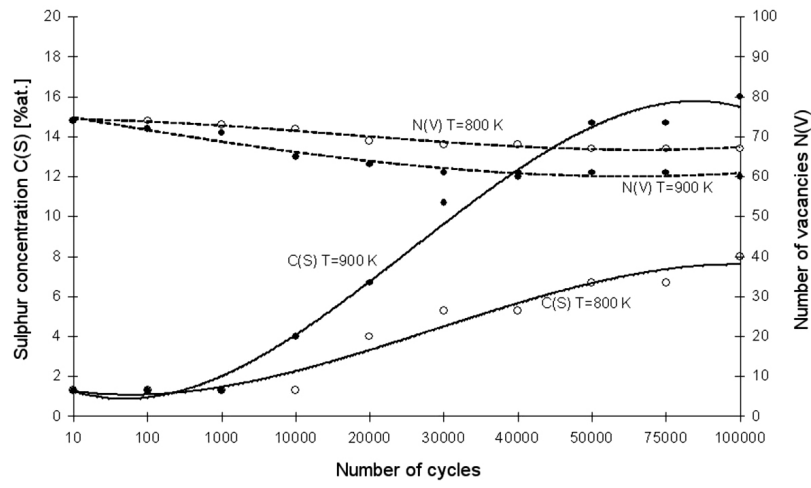

Figure 13: Effect of the diffusion temperature on the relation between the sulphur concentration and number of vacancies on the number of diffusion-simulation cycles concerning the model alloy $\mathrm{Cu}-0.75 \%$ amount fraction of $\mathrm{S}$ and the matrix of $100 \times 100$ atoms

Slika 13: Učinek difuzije temperature na relacijo med žveplovo koncentracijo in številom vrzeli difuzijsko stimulacijskih ciklov pri modelu zlitine $\mathrm{Cu}-0,75 \%$ atomskih deležev $\mathrm{S}$ in matriki $100 \times 100$ atomov 


\section{MATERIALI IN TEHNOLOGIJE/MATERIALS AND TECHNOLOGY (1967-2017) - 50 LET/50 YEARS}

W. OZGOWICZ: NUMERICAL SIMULATION OF AN EQUILIBRIUM SEGREGATION OF IMPURITIES ...

Table 3: Energy of migration and bonding of the lattice defects calculated for the model alloy Cu-3 \% amount fraction of Sn Tabela 3: Energija migracij in povezovanja mrežnih pomanjkljivosti za model $\mathrm{Cu}-3 \%$ atomskih deležev $\mathrm{Sn}$

\begin{tabular}{|c|c|c|c|c|c|}
\hline \multirow[b]{2}{*}{ Kind of energy } & \multicolumn{5}{|c|}{ Kind of the lattice defect } \\
\hline & Vacancy (v) & Divacancy (vv) & Impurity atom (i) & $\begin{array}{l}\text { Complex biatomic } \\
\text { impurity (ii) }\end{array}$ & $\begin{array}{l}\text { Complex vacancy- } \\
\text { impurity (vi) }\end{array}$ \\
\hline Forming energy $E_{\mathrm{f}}(\mathrm{eV})$ & 1.49 & 2.87 & 1.65 & 3.23 & 4.27 \\
\hline Migration energy $E_{\mathrm{m}}(\mathrm{eV})$ & 1.49 & - & 1.65 & - & - \\
\hline \multirow{2}{*}{ Kind of defect } & \multicolumn{5}{|c|}{ Energy of bonding $E_{b}(\mathrm{eV})$} \\
\hline & Vacancy & Impurity atom & \multicolumn{3}{|c|}{ Grain boundary } \\
\hline Vacancy & 0.14 & $1.04 * \quad 1.13$ & \multicolumn{3}{|c|}{1.49} \\
\hline Impurity atom & $1.04 *$ & $0.22 *$ & \multicolumn{2}{|c|}{$0.3 *$} & \\
\hline Grain boundary & 1.49 & $0.3^{*}$ & \multicolumn{3}{|c|}{0.20} \\
\hline
\end{tabular}

* alternative values adopted to program the simulation

the calculated values of the energy of the effect of point defects the concentration of the atoms of tin at the grain boundary of a (2D) structure increases only slightly with the growing number of iterated cycles, whereas the number of free vacancies in the matrix practically does not change at all, Figure 14. After about $10^{3}$ iterated cycles, we can merely observe the effect of the grain boundary as the sink of vacancies without any visible change in the concentration of the atoms of tin in the zone adjacent to the boundary.

A detailed analysis of the changes in the concentration of $\mathrm{C}(\mathrm{Sn})$ and $\mathrm{C}(\mathrm{V})$ in the function of the distance from the grain boundary permits us to state that, in this stage of simulating the diffusion, we can observe a distinct formation of potential areas of clusters of tin atoms and vacancies. An insignificant enrichment of tin at the grain boundary (about $7 \%$ amount fraction) and an evident localisation of the cluster of $\left(\mathrm{Sn}_{\mathrm{M}} \mathrm{V}_{\mathrm{M}}\right)$ were, however, seen after about $10^{5}$ cycles of the simulation, Figure 15.

Computer-aided simulations of lattice diffusion, accomplished on the basis of the newly developed software DYFUZJA, confirmed the possibility of segregations of atoms of $\mathrm{S}$ and $\mathrm{Sn}$ generated at the grain boundary of the model structure (2D) of the analysed

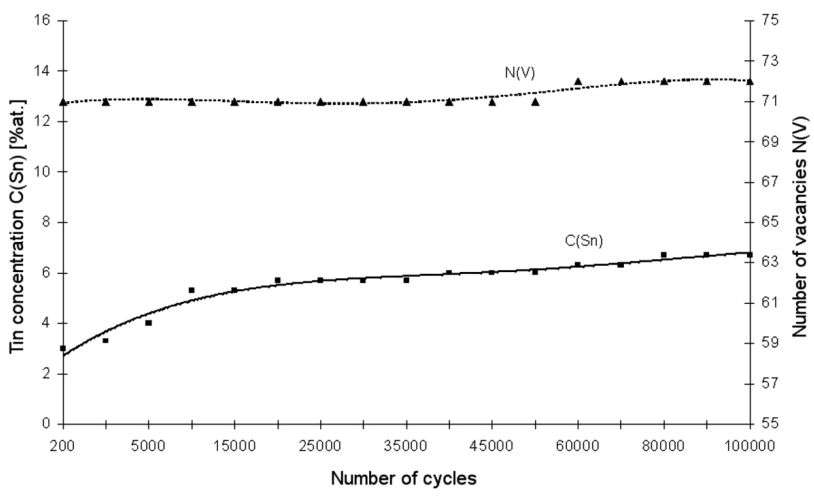

Figure 14: Dependence of the tin concentration and number of vacancies on the number of diffusion-simulation cycles concerning the model bronze $\mathrm{Cu}-3 \%$ amount fraction of $\mathrm{Sn}$ and $T=1000 \mathrm{~K}$

Slika 14: Odvisnost koncentracije kositra in število vrzeli glede na število difuzijskih simulacijskih ciklov glede na model brona $\mathrm{Cu}-3 \%$ atomskih deležev $\mathrm{Sn}$ in $T=1000 \mathrm{~K}$ alloys of copper composed of $\mathrm{Cu}-0.75 \%$ amount fraction of S, Figures 8-13, and $\mathrm{Cu}-3 \%$ amount fraction of $\mathrm{Sn}$, Figures 14 and 15. The obtained results coincide, more or less, with the AES experimental results.
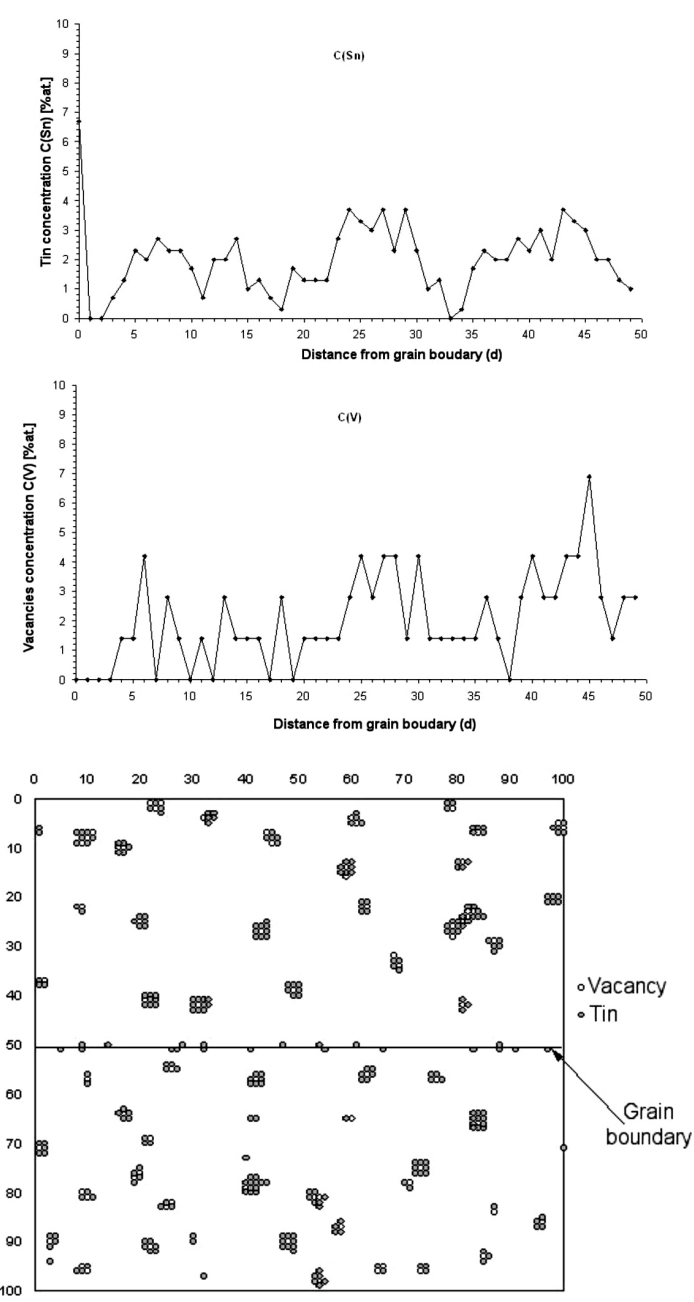

Figure 15: Distribution of tin and vacancy concentrations as a function of the distance from the grain boundary concerning the model bronze $\mathrm{Cu}-3 \%$ amount fraction of $\mathrm{Sn}$ and $T=1000 \mathrm{~K}$ after a simulation of 105 cycles

Slika 15: Razpršenost kositra in koncentracije vrzeli kot funkcije razdalj od mej zrn glede na model brona $\mathrm{Cu}-3 \%$ atomskih deležev $\mathrm{Sn}$ in $T=1000 \mathrm{~K}$ po simulaciji 150 ciklov 
An important problem concerning the attainment of reliable results of a computer-aided simulation of the migration of admixture atoms or impurities to the grain boundary of a (2D) structure is, besides the correctness of the assumed mathematical model, the application of adequate data to the simulative calculations, mainly the physical quantities describing the elements of the computer model and the simulated process. These quantities are usually not available in the literature. The model must take into account the energy of bonding of the point defects with each other $\left(E_{b}^{\text {didj }}\right)$, e.g., $E_{b}^{v v}, E_{b}^{v i}, E_{b}^{i i}$ as well as the energy that bonds them with the grain boundary ( $\left.E_{b}^{d i b}\right)$, e.g., $E_{b}^{i b}, E_{b}^{v b}$ where $d_{1}, d_{2} \ldots$ denote the numbers expressing the kind of point defects (vacancies, alloy atoms or impurities) and also the respective energy of migration $\left(E_{b}^{d i}\right)$, Tables 4.2-4.5. The methods for determining the energy of bonding $E_{b}^{v v}, E_{b}^{i i}$ or $E_{b}^{v i}$ differ considerably from each other, and the obtained results indicate a large scattering of these values ${ }^{11}$. In spite of the fact that the methods of calculations take into account both the elements of the theory of elasticity and the electron factors, as well as the valencies of the formed pairs of distances and the values of their inter-atomic potentials of the Morse type, the degree of accuracy of these methods is still uncertain.

\section{CONCLUSION}

The results of the performed experimental investigations and the numerical analysis concerning the processes of diffusive intercrystalline segregations in tin bronzes lead to the formulation of the following conclusions:

The Auger spectrometric analysis of the intercrystalline fractures in single-phase tin bronze of the CuSn6P type, stretched in the DMT range, carried out in situ, indicates a segregation of the atoms of $\mathrm{S}$ and $\mathrm{Sn}$ with various intensities depending mainly on the temperature of deformation.

Computer simulations of the process of lattice vacancy diffusion confirm the variated possibility of the segregation of the atoms of sulphur and tin generated at the grain boundary in the two-dimensional model structure of the theoretically analysed copper alloys with the following composition: $\mathrm{Cu}-0.75 \%$ amount fraction of $\mathrm{S}$ and $\mathrm{Cu}-3 \%$ amount fraction of $\mathrm{Sn}$. The effect of the segregations in the atomic nanolayer at the grain boundary in the $\mathrm{Cu}-\mathrm{S}$ system and a merely slight effect of enrichment of this atomic layer of Sn are quite evident in the case of the $\mathrm{Cu}-\mathrm{Sn}$ composition.

The newly developed programme of computer-aided simulation DYFUZJA, in the actual version, permits us to simulate and visualize the atomic diffusion to the grain boundary of a modelled (2D) structure, taking into account the maximum of four different admixture elements or impurities in the function of the concentration of the investigated elements and vacancies in the matrix of the alloy: the temperature of diffusion, the preliminarily calculated values of the energy of the effects of lattice defects, the size of the atomic plane and the value of the coefficient of acceleration.

The simulated effects of the segregation of atoms to the grain boundary, analysed as a function of the number of the cycles of the simulation are characterized by a statistically good repeatability of the results.

\section{REFERENCES}

${ }^{1}$ E. D. Hondros, M. P. Seah, Segregation to Interfaces, International Metals Review, 222 (1977), 262-301

${ }^{2} \mathrm{M}$. P. Seah, Grain boundary segregation and the $T-t$ dependence of temper brittleness, Acta Metallurgica, 25 (1977) 3, 345-357, doi:10.1016/0001-6160(77)90153-5

${ }^{3}$ R. G. Faulkner, Non-equilibrium grain-boundary segregation in austenitic alloys, Journal of Materials Science, 16 (1981), 373-383, 10.1007/BF00738626

${ }^{4}$ K. T. Aust, S. J. Armijo, E. F. Koch, J. A. Westbrook, Vacancydriven grain boundary segregation, Transactions ASM, 60 (1967), 360

${ }^{5}$ R. Anthony, Solute segregation in vacancy gradients generated by sintering and temperature changes, Acta Metallurgica, 17 (1969), 603-609, doi:10.1016/0001-6160(69)90120-5

${ }^{6}$ T. M. Williams, A. M. Stoneham, D. R. Harries, The segregation of boron to grain boundaries in solution-treated Type 316 austenitic stainless steel, Metal Science, 10 (1976), 14-19, doi:10.1179/ 030634576790431471

${ }^{7}$ P. Doig, J. Flewitt, Segregation of chromium to prior austenite boundaries during quenching of a $214 \% \mathrm{Crl} \%$ Mo steel, Acta Metallurgica, 29 (1981) 11, 1831-1841, doi:10.1016/0001-6160(81)90109-7

${ }^{8}$ R. G. Faulkner, Combined grain boundary equilibrium and non-equilibrium segregation in ferritic/martensitic steels, Acta Metallurgica, 35 (1987) 12, 2905-2914, doi:10.1016/0001-6160(87)90289-6

${ }^{9}$ R. Rice, Effect of Hydrogen on Behavior of Materials, Metallurgical Society of AIME, New York, (1976), 455-466

${ }^{10}$ D. McLean, Grain boundaries in metals, Oxford Univ. Press, 1957

${ }^{11}$ M. A. V. Chapman, R. G. Faulkner, Computer modelling of grain boundary segregation, Acta Metallurgica, 31 (1983), 677-689, doi:10.1016/0001-6160(83)90083-4

${ }^{12}$ C. Waite, R. G. Faulkner, A new computer model of grain boundary segregation, Journal of Materials Science, 25 (1990), 649-653, doi:10.1007/BF00714089

${ }^{13}$ R. G. Faulkner, Grain boundary non-equilibrium segregation in steels, Journal de Physique Colloques, 51 (1990) C1, 133-138

${ }^{14}$ H. Jiang, R. G. Faulkner, Modelling of grain boundary segregation, precipitation and precipitate-free zones of high strength aluminium alloys - II. Application of the models, Acta Materialia, 44 (1996) 5 , 1865-1871, doi:10.1016/1359-6454(95)00318-5

${ }^{15}$ S. Mrowec: Theory of diffusion in solid state, PWN, Warsaw (1989)

${ }^{16}$ O. H. Wyatt, D. Dew Hughes, Metals, ceramics and polymers, Cambridge University Press, Cambridge, 1974, ISBN 10: 0521082382, ISBN 13: 9780521082389

${ }^{17}$ W. Ozgowicz, M. Biscondi, High-Temperature Brittleness and Interfacial Segregation in Tin Bronzes, Journal de Physique IV Colloque, 05 (1995) C7, 315-320, doi:10.1051/jp4:1995738>.<jpa-00254032>

${ }^{18}$ W. Ozgowicz, Zastosowanie analizy Augera w próbach rozciągania na gorąco miedzi i jej stopów, Materials, mechanical \& manufacturing engineering, M3E'2000, Proceedings of the scientific conference, Gliwice, 2000, 221-226

${ }^{19}$ W. Ozgowicz, E. Kosek, Computer simulation of the diffusive segregation of impurities on the grain boundaries of metallic polycrystals, Archiwum nauki o materiałach, 2 (2004), 93-112 
W. OZGOWICZ: NUMERICAL SIMULATION OF AN EQUILIBRIUM SEGREGATION OF IMPURITIES ...

${ }^{20}$ W. Ozgowicz, Physico-chemical, structural and mechanical factors of intergranular brittleness of $\alpha$-bronzes at elevated temperature, Silesian Techn. Univ., Gliwice, Mechanics, Z.145 (2004) (in Polish)

${ }^{21}$ W. Ozgowicz, KBN Report, Nr. 7T08A02517, Silesian Techn. Univ.,

Gliwice, 2002 